\title{
Students' Perspective about E-Learning Problems and its Benefits
}

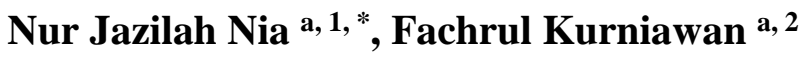 \\ ${ }^{a}$ Universitas Islam Negeri Maulana Malik Ibrahim, Malang, Indonesia \\ ${ }^{1}$ 4ur.zil@gmail.com; ${ }^{2}$ fachrulk@ti.uin-malang.ac.id
}

\begin{tabular}{|c|c|}
\hline Article Info & $\begin{array}{l}\text { ABSTRACT } \\
\end{array}$ \\
\hline $\begin{array}{l}\text { Article history: } \\
\text { Received: March 3, } 2019 \\
\text { Revised: April 1, } 2019 \\
\text { Accepted: April 17, } 2019\end{array}$ & $\begin{array}{l}\text { Current technological developments force prospective educators to follow and even } \\
\text { exploit its development to support the instructor and students. Besides that, we cannot } \\
\text { simply move on with its rapid development now. E-Learning is one of the } \\
\text { breakthroughs in the field of education that is allegedly able to improve the quality and } \\
\text { quality of students in learning. For that prospective educators must also understand } \\
\text { what E-Learning is. The purpose of this research is to determine the level of } \\
\text { understanding of students majoring in education at UIN MALIKI Malang about E- } \\
\text { Learning and its utilization for students. In order to make adjustments to the } \\
\text { education curriculum at the PTN level related to the issue of E-Learning itself. The } \\
\text { author will conduct interviews indirectly with interviewees to ask about E-Learning } \\
\text { problems and its benefits. After conducting research it shows that 54.1\% of students } \\
\text { have not fully understood about this issues. }\end{array}$ \\
\hline
\end{tabular}

\section{INTRODUCTION}

E-learning is a new way of teaching and learning that uses electronic media, especially the internet as a learning system [1]. E-learning is the basis and logical consequence of the development of information and communication technology [2], [3]. Some experts try to describe the meaning of elearning according to their respective versions. E-learning as just any teaching and learning that uses electronic circuits (LAN, WAN, or internet) to convey the contents of learning, interaction, or guidance.

E-learning as asynchronous learning activities through computer electronic devices that obtain learning material that suits their needs. E-learning refers to the use of internet technology to send a series of solutions that can enhance knowledge and skills [4]. E-Learning is a type of teaching and learning that enables the delivery of teaching materials to students using Internet media, Intranet or other computer network media. E-Learning is an educational system that uses electronic applications to support teaching and learning with Internet media, computer networks, or standalone computers.

E-learning can include learning done in the media electronic (internet) both formally and informally [5], [6]. E- learning formally is learning with curriculum, syllabus, subjects and tests that have been arranged and arranged according to a schedule agreed upon by related parties (elearning managers and learners themselves). Learning like this is usually a high level of interaction and is required by the company to its employees or distance learning managed by universities and companies (usually consulting companies) that are engaged in providing e-learning services to the public. E-learning can also be done informally with simpler interactions, for example through mailing lists, e-newsletters or personal websites, organizations and companies that want to socialize certain services, programs, knowledge or skills to the wider community.

\section{AdVANTAGES AND DiSADVANTAGES OF E-LEARNING}

E-learning has shortened learning time and made study costs more economical. It facilitates interaction between students and materials, students and educators and fellow students [7]. Students can share information and can access learning materials at any time and repeated, with such conditions students can strengthen their mastery of learning materials [8]. In e-learning, the factor of educators attendance automatically becomes reduced or even absent. This is because those who take the teacher's role are computers and 
electronic guides designed by "content writers", e-learning designers and computer programmers. Moreover there are several infrastructures of e-learning such as [9]-[11]:

- E-learning Systems and Applications Science education: The e-learning software system is a system that virtualizes the teaching and conventional learning process. This virtualization such as classroom management, material or content creation, discussion forums, discussion groups, assessment systems, online examination systems and some features related to learning management such as depositing assignments and accessing information about assignments received including grades obtained.

- Educational E-learning Content: Content and teaching material available in E-learning Educational science is a system that provides a management system that contains content and teaching materials in the form of Multimedia-based content or Text-based Content.

\section{METHOD}

A data collection in this study using questionnaire technique. It will provides to correspondents or informants were chosen randomly from several departments of education at the State Islamic University of Maulana Malik Ibrahim Malang. There are 5 questions that must be answered, consisting of 2 multiple choices and 3 descriptions, which will determine the results of the research conducted. After that the researcher will calculate and analyze the results to draw a conclusions.

\section{RESULT AND DISCUSSION}

TABLE I. QUESTIONNAIRE RESULT

\begin{tabular}{lllllllll}
\hline Respondent & Department & Semester & from & \multicolumn{5}{c}{ Question } \\
\cline { 5 - 8 } & & & & & $\mathbf{1}$ & $\mathbf{3}$ & $\mathbf{4}$ & $\mathbf{5}$ \\
\hline 1 & SSE & 7 & SHS & 1 & 1 & 1 & 1 & 1 \\
2 & MITE & 3 & & 1 & 1 & 1 & 1 & \\
3 & SSE & 7 & & 1 & 1 & 1 & 1 & 1 \\
4 & SSE & 7 & & 1 & & 1 & 1 & \\
5 & SSE & 7 & & 1 & & 1 & 1 & 1 \\
6 & ALE & 7 & MA & 1 & 1 & 1 & 1 & 1 \\
7 & ALE & 5 & SHS & 1 & & & 1 & \\
8 & ALE & 5 & & 1 & & 1 & 1 & \\
9 & ALE & 5 & MA & 1 & & 1 & 1 & \\
10 & ALE & 5 & SHS & 1 & 1 & 1 & 1 & \\
11 & ALE & 7 & MA & 1 & & & 0 & \\
12 & IE & 1 & SHS & 1 & & & 1 & 1 \\
13 & IE & 1 & & 1 & & 1 & 1 & 1 \\
14 & ALE & 7 & MA & 1 & 1 & 1 & 1 & 1 \\
15 & ALE & 7 & VHS & 1 & 1 & & 1 & 1 \\
16 & ALE & 7 & SHS & 1 & 1 & 1 & 1 & 1 \\
17 & ALE & 7 & MA & 1 & & 1 & 1 & 1 \\
18 & ALE & 7 & SHS & 1 & & 1 & 1 & 1 \\
19 & ALE & 7 & MA & 1 & & & 1 & \\
20 & ALE & 3 & MA & 1 & 1 & 1 & 1 & \\
21 & ALE & 3 & MA & 1 & 1 & & 1 & \\
22 & ALE & 3 & MA & 1 & & 1 & 1 & \\
23 & ALE & 3 & MA & 1 & 1 & 1 & 1 & 1 \\
24 & ALE & 5 & MA & 1 & & & 1 & \\
\hline
\end{tabular}

Table 1 shows the questionnaire result. The respondents are from several department when SSE is stands for social science education, MITE stands for Madrasah ibtidaiyah teacher education, ALE stands for Arabic language education, and IE stands for Islamic education.

After interviews with respondents, they all knew about ELearning. But, when asked to explain what E-learning was, $54.1 \%$ could not answer. In addition, almost all agree that Elearning can help the learning activity. Moreover, there are ELearning categories which were good according to respondents, such as:

- 3D based

- Easy to understand

- Can make students more active

- Supporting the learning activity

- Afford the students' ability

- Students are more developed

- Do not deviate from the main purposes

- Interesting

- Learning objectives achieved

- Increase motivation

- Helps students to understand

\section{CONCLUSION}

After conducting research, result shows that more than $50 \%$ students do not understand E-Learning. For this reason, it is necessary to increase the understanding of E-Learning at the higher education level.

\section{References}

[1] M. Aparicio, F. Bacao, and T. Oliveira, "An e-learning theoretical framework,” J. Educ. Technol. Soc., vol. 19, no. 1, pp. 292-307, 2016.

[2] M. J. Rosenberg and R. Foshay, "E-learning: Strategies for delivering knowledge in the digital age," Perform. Improv., vol. 41, no. 5, pp. 50$51,2002$.

[3] D. Zhang, J. L. Zhao, L. Zhou, and J. F. Nunamaker Jr, "Can e-learning replace classroom learning?," Commun. ACM, vol. 47, no. 5, pp. 75-79, 2004.

[4] M. J. Rosenberg, Beyond e-learning: Approaches and technologies to enhance organizational knowledge, learning, and performance. San Francisco, CA: John Wiley \& Sons, 2005.

[5] B. Gros and F. J. García-Peñalvo, "Future trends in the design strategies and technological affordances of e-learning," in Learning, Design, and Technology: An International Compendium of Theory, Research, Practice, and Policy, M.Spector, B. B. Lockee, and M. D. Childress, Eds. Switzerland: Springer International Publishing, 2016, pp. 1-23.

[6] C. Greenhow and C. Lewin, "Social media and education: Reconceptualizing the boundaries of formal and informal learning," Learn. Media Technol., vol. 41, no. 1, pp. 6-30, 2016.

[7] V. Arkorful and N. Abaidoo, "The role of e-learning, advantages and disadvantages of its adoption in higher education," Int. J. Instr. Technol. Distance Learn., vol. 12, no. 1, pp. 29-42, 2015.

[8] S. R. Harandi, "Effects of e-learning on Students' Motivation," Procedia-Social Behav. Sci., vol. 181, pp. 423-430, 2015. 
[9] J. Ismail, "The design of an e-learning system: Beyond the hype," internet High. Educ., vol. 4, no. 3-4, pp. 329-336, 2001.

[10] X. Liu, A. El Saddik, and N. D. Georganas, "An implementable architecture of an e-learning system," in CCECE 2003-Canadian Conference on Electrical and Computer Engineering. Toward a Caring and Humane Technology, 2003, pp. 717-720.

[11] Ö. Özyurt and H. Özyurt, "Learning style based individualized adaptive e-learning environments: Content analysis of the articles published from 2005 to 2014," Comput. Human Behav., vol. 52, pp. 349-358, 2015. 